Nevada

Environmental

Restoration

Project

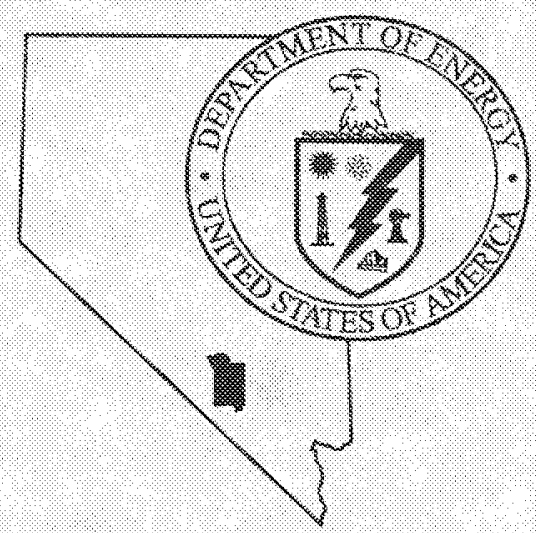

\title{
Addendum to Closure Report For Housekeeping Category Corrective Action Unit 354 Nevada Test Site, Nevada
}

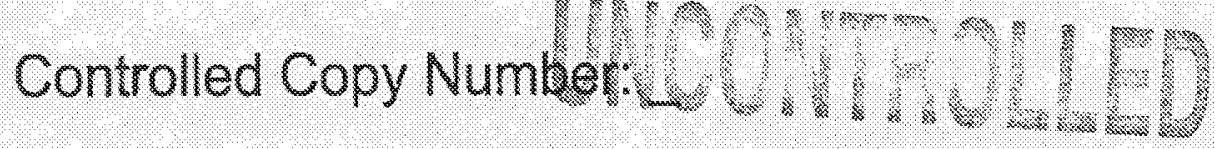

Revision: 0

May 1999

Distribution A - Approved for public release; further dissemination unlimited.

Environmental Restoration

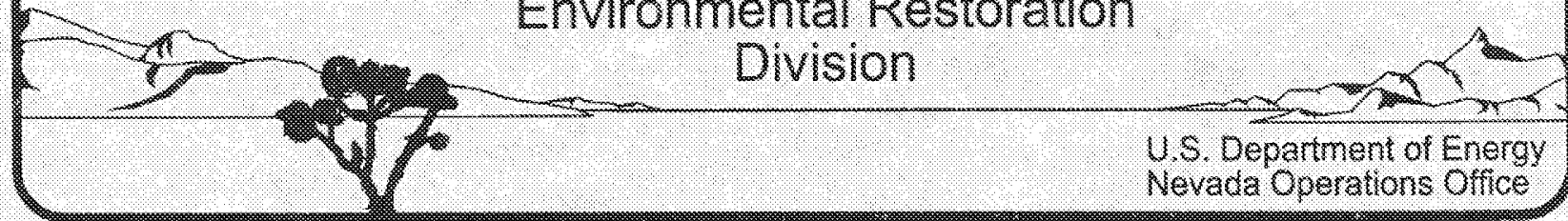


Available to the public from:

U. S. Devamment of Commerce

National Technical Information Service

5285 Port Royal Road

Springfield, V 1 22161

(703) $487-4650$

Available electronically at htro//www doe.gov/bridge. Available to the U.S. Department of Energy and its contractors in paper from:

U.S. Deparment of Energy

Office of Scienufic and Technical Information

P.O. Box 62

Oak Ridge, TN $37831 \% 0062$

(423) $576-8401$

Reference herein to any specific commercial product, process, or service by trade name, trademark, manwiacturer, or otherwise, does not necessarily constitute or imply its endorsement, recommendation, or favoring by the U.S. Government or any agency thereof or its contractors or subcontractors. 


\section{ADDENDUM TO \\ CLOSURE REPORT FOR HOUSEKEEPING CATEGORY \\ CORRECTIVE ACTION UNIT 354 \\ NEVADA TEST SITE}

Controlled Copy No.:

Revision: 0

May 1999

Prepared for the U.S. Department of Energy Nevada Operations Office

Work Performed Under Contract No. DE-AC08-96NV11718 
ADDENDUM TO

CLOSURE REPORT FOR HOUSEKEEPING CATEGORY CORRECTIVE ACTION UNIT 354

NEVADA TEST SITE

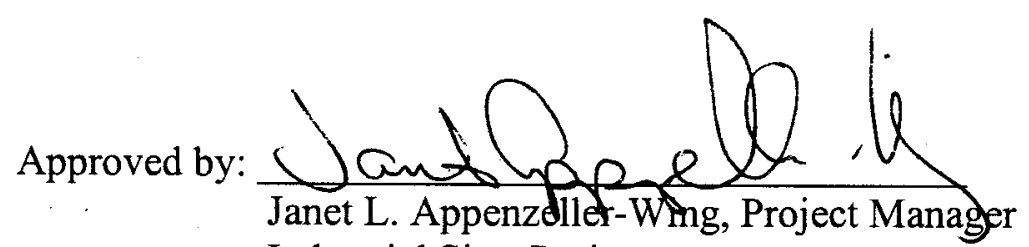

Industrial Sites Project

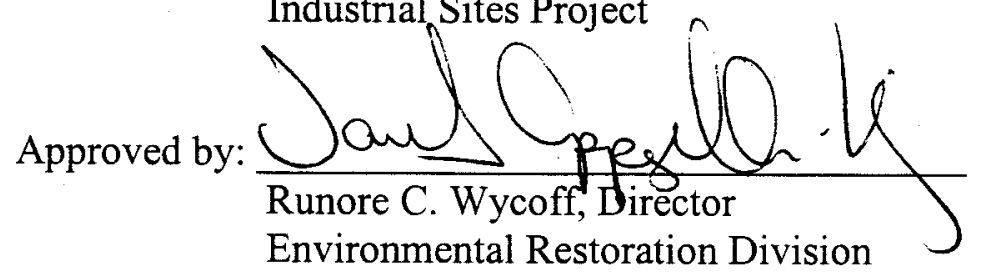

Date: $6 / 2 / 99$

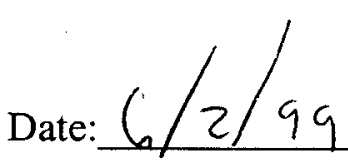

iii 


\section{INTRODUCTION}

This Closure Report Addendum for Corrective Action Unit (CAU) 354 summarizes the disposition of four Corrective Action Sites (CASs) located in Area 25 of the Nevada Test Site (NTS), Nevada. These sites were excluded from the January 1998 Closure Report for CAU 354 (DOE/NV, 1998) because they were determined to require corrective actions which were outside the scope of work as defined in the Housekeeping Category Corrective Action Unit Work Plan (DOE/NV, 1996). Table 1 provides a description of each CAS and its status with respect to the Federal Facilities Agreement and Consent Order (FFACO, 1996) and agreements made with the Nevada Division of Environmental Protection (NDEP). Copies of the Housekeeping Closure Verification Forms for each CAS are included in Attachment A.

\section{TABLE 1 - SUMMARY OF CAS DISPOSITION}

\begin{tabular}{||c|l|l||}
\hline CAS NUMBER & \multicolumn{1}{|c|}{$\begin{array}{c}\text { DESCRIPTION OF } \\
\text { CAS }\end{array}$} & \multicolumn{1}{|c|}{ STATUS } \\
\hline \hline $25-22-02$ & $\begin{array}{l}\text { Drums (2) } \\
-208 \text { liter (55 gallon) } \\
- \text { containing oil }\end{array}$ & $\begin{array}{l}\text { Drums have been previously removed. } \\
\text { Light excavation of hydrocarbon- } \\
\text { impacted soils was conducted. This CAS } \\
\text { requires additional excavation for } \\
\text { complete cleanup. On June 29, 1998, } \\
\text { NDEP approved transferring the stained } \\
\text { soil from CAS 25-22-02 to a new CAS } \\
\text { 25-44-02. This new CAS will be grouped } \\
\text { with CAU 398, Area 25 Spill Sites, in } \\
\text { Appendix II of the FFACO. }\end{array}$ \\
\hline $25-22-13$ & Drums & $\begin{array}{l}\text { Some drums, containing hydraulic fluid, } \\
\text { have been previously removed. } \\
\text { Remaining drums contain usable product. } \\
\text { In June 1998, this CAS was demoted to } \\
\text { CAU 501 in Appendix II of the FFACO. } \\
\text { In October 1998, NDEP approved the } \\
\text { transfer of this CAS into CAU 5000. }\end{array}$ \\
\hline -208 liter (55 gallon) & & $\begin{array}{l}\text { A series of batteries and one diesel tank } \\
\text { are still at this location. In June 1998, this } \\
\text { CAS had been demoted to CAU 501 in } \\
\text { Appendix II of the FFACO. In October } \\
\text { 1998, NDEP approved the transfer of this } \\
\text { CAS into CAU 5000. }\end{array}$ \\
\hline $25-24-16$ & Batteries &
\end{tabular}




\begin{tabular}{|c|c|c|}
\hline CAS NUMBER & $\begin{array}{l}\text { DESCRIPTION OF } \\
\text { CAS }\end{array}$ & STATUS \\
\hline $25-27-01$ & $\begin{array}{l}\text { Drums (2) } \\
\text {-208 liter (55-gallon) } \\
\text { - marked "PCB's" }\end{array}$ & $\begin{array}{l}\text { Drums, containing polychlorinated } \\
\text { biphenyl (PCB) waste, have been } \\
\text { previously removed. Discolored areas } \\
\text { found on the surface soil and surrounding } \\
\text { debris require additional action. On June } \\
29,1998 \text {, NDEP approved transferring } \\
\text { stained soil from CAS } 25-27-01 \text { to a new } \\
\text { CAS } 25-44-03 \text {. This new CAS will be } \\
\text { grouped with CAU 398, Area } 25 \text { Spill } \\
\text { Sites, in Appendix II of the FFACO. }\end{array}$ \\
\hline
\end{tabular}




\section{REFERENCES}

DOE/NV, see U. S. Department of Energy, Nevada Operations Office.

U. S. Department of Energy, Nevada Operations Office, 1996, Housekeeping Category Corrective Action Unit Work Plan, DOE/NV-452, UC-700, Las Vegas, Nevada.

U. S. Department of Energy, Nevada Operations Office, 1998, Closure Report for Housekeeping Category Corrective Action Unit 354 Nevada Test Site, DOE/NV-11718-169, UC-702, Las Vegas, Nevada.

FFACO, see Federal Facilities Agreement and Consent Order.

Federal Facilities Agreement and Consent Order, 1996, Agreed to by the Nevada Division of Environmental Protection, the U.S. Department of Energy, and the U.S. Department of Defense. 
ATTACHMENT A

HOUSEKEEPING CLOSURE VERIFICATION FORMS 


\title{
FFACO CORRECTIVE ACTION SITE Housekeeping Closure VERIFICATION Form
}

Closure Verification Date: April 30, 1997

$\begin{aligned} \text { CAS Number: } & 25-22-02 \\ \text { General Location: } & \text { Test Cell A } \\ \text { Latitude: } & \\ \text { Longitude: } & \end{aligned}$

\author{
CAU Number: 354 \\ Elevation: \\ Northing: $757,246.888$ \\ Easting: $619,481.970$
}

Coordinate/Elevation Data Obtained from Garmen 40 Global Position System: Accuracy is within 300 feet Horizontal - Vertical Varies with Locality

Site Access Route: From Mercury, proceed southwest on Jackass Flats Road to Area 25, through Gate 500. Proceed north on C-Road and follow as it curves east into F-Road. Test Cell A is located on the left (north) side of the road. The CAS is west of the main test cell building near a pipe frame structure on a concrete pad.

\begin{tabular}{|l|l|}
\hline \multicolumn{1}{|c|}{ Waste Item(s) Originally at Site } & \multicolumn{1}{|c|}{ Apparent Waste Type* $^{*}$} \\
\hline Drums (2) & Hydrocarbon waste \\
\hline * Ordinary, Scrap Metal, Asbestos, PCB, Salvageable, Hazardous, Radioactive, Mixed, Unknown, Other
\end{tabular}

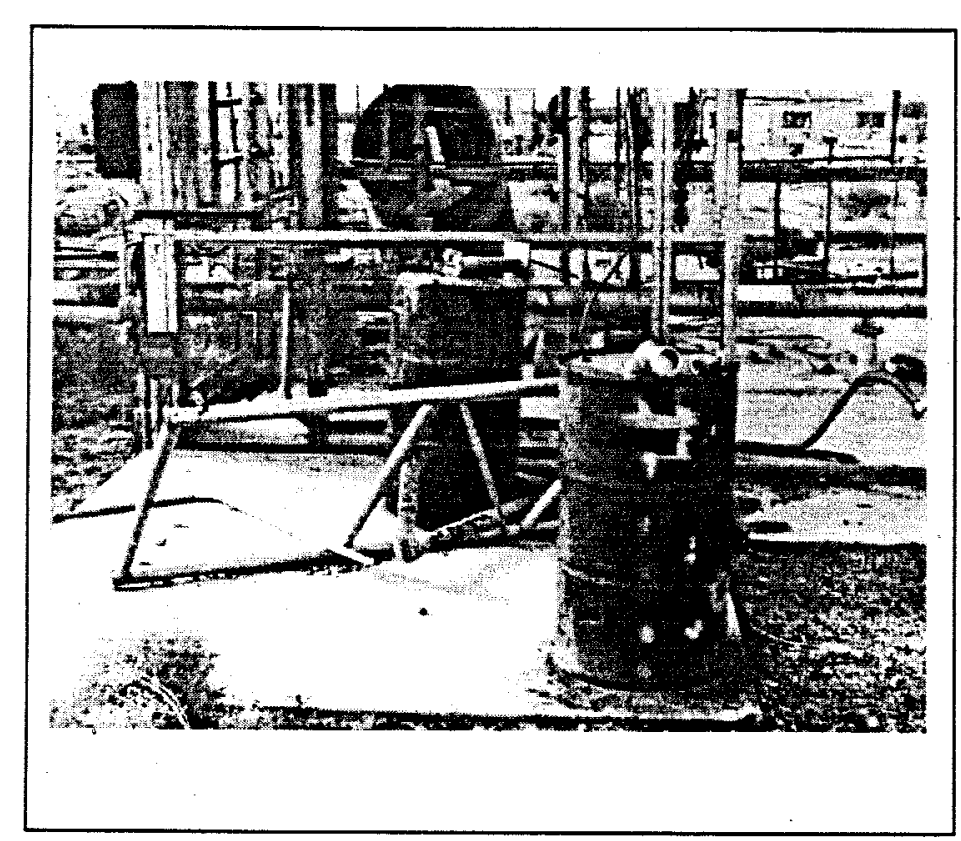

CAS Prior Status- October 5, 1990

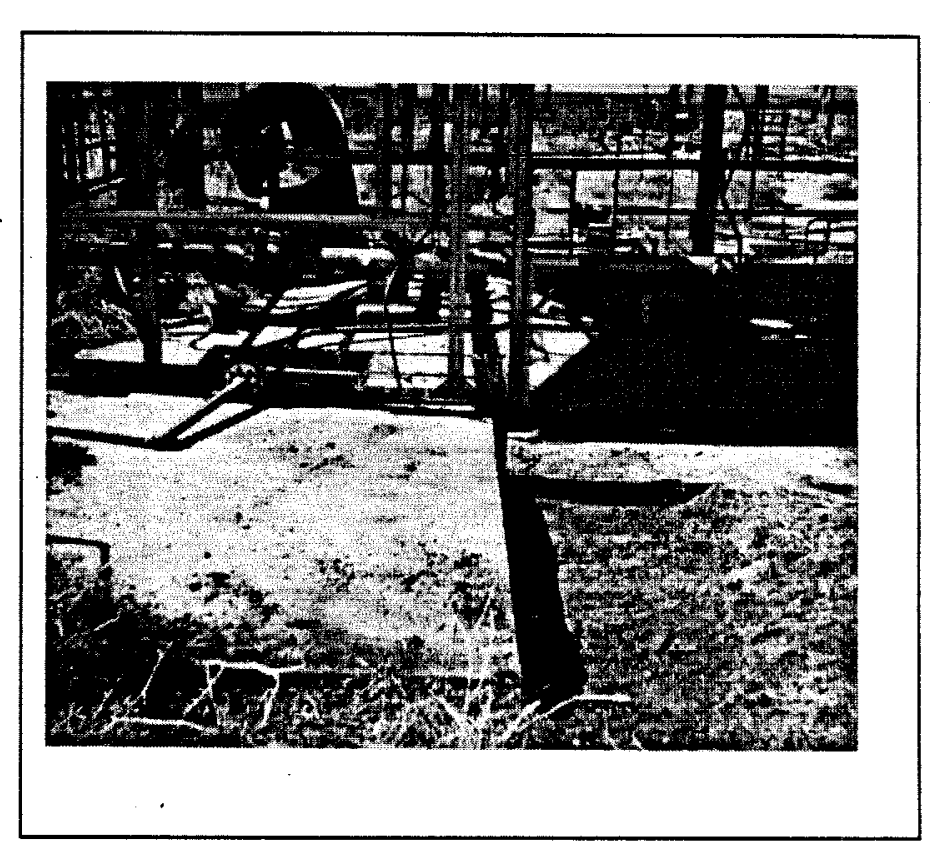

CAS Current Status- April 30, 1997

Current Site Description/Observations: The CAS was originally identified on October 5, 1990. It was verified that the drums had been removed but the discolored soil remained. Available sampling and analysis data indicates that the soil is impacted with petroleum hydrocarbons. Surface soils were excavated and disposed of in the Area 6 Hydrocarbon Landfill. The results of a Petroflag ${ }^{\mathrm{TM}}$ hydrocarbon field test kit indicates that additional excavation is necessary. Lead materials found in the vicinity were also retrieved and recycled.

$\times \quad$ Stained soil was transferred to a new CAS 25-44-02 and grouped with CAU 398, Area 25 Spill Sites

C. Carlos Gonzales

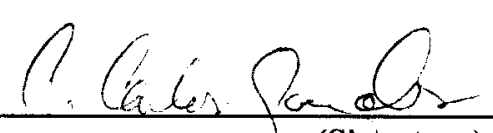
$5 / 2>19$

Corrective Action Coordinator/Designee

(Signature)

Date 


\section{FFACO CORRECTIVE ACTION SITE HoUSEKEEPING ClOSURE VERIFICATION FORM}

Closure Verification Date: April 30, 1997

CAS Number: 25-22-13

CAU Number: 354

General Location: E-MAD Facility Latitude:

Elevation:

Longitude:

Northing: 748,500

Easting: 605,500

Coordinate/Elevation Data Obtained from Garmen 40 Global Position System: Accuracy is within 300 feet Horizontal - Vertical Varies with Locality

Site Access Route: From Mercury, proceed southwest on Jackass Flats Road to Area 25, through Gate 500. Proceed north on C-Road and turn left (west) on H-Road. At E-MAD turnoff, turn left (south) into the fenced compound. The drums are located in the basement generator room.

\begin{tabular}{|l|l|}
\hline \multicolumn{1}{|c|}{ Waste Item(s) Originally at Site } & \multicolumn{1}{|c|}{ Apparent Waste Type* $^{*}$} \\
\hline Drums & Hydrocarbon (potential) \\
\hline
\end{tabular}

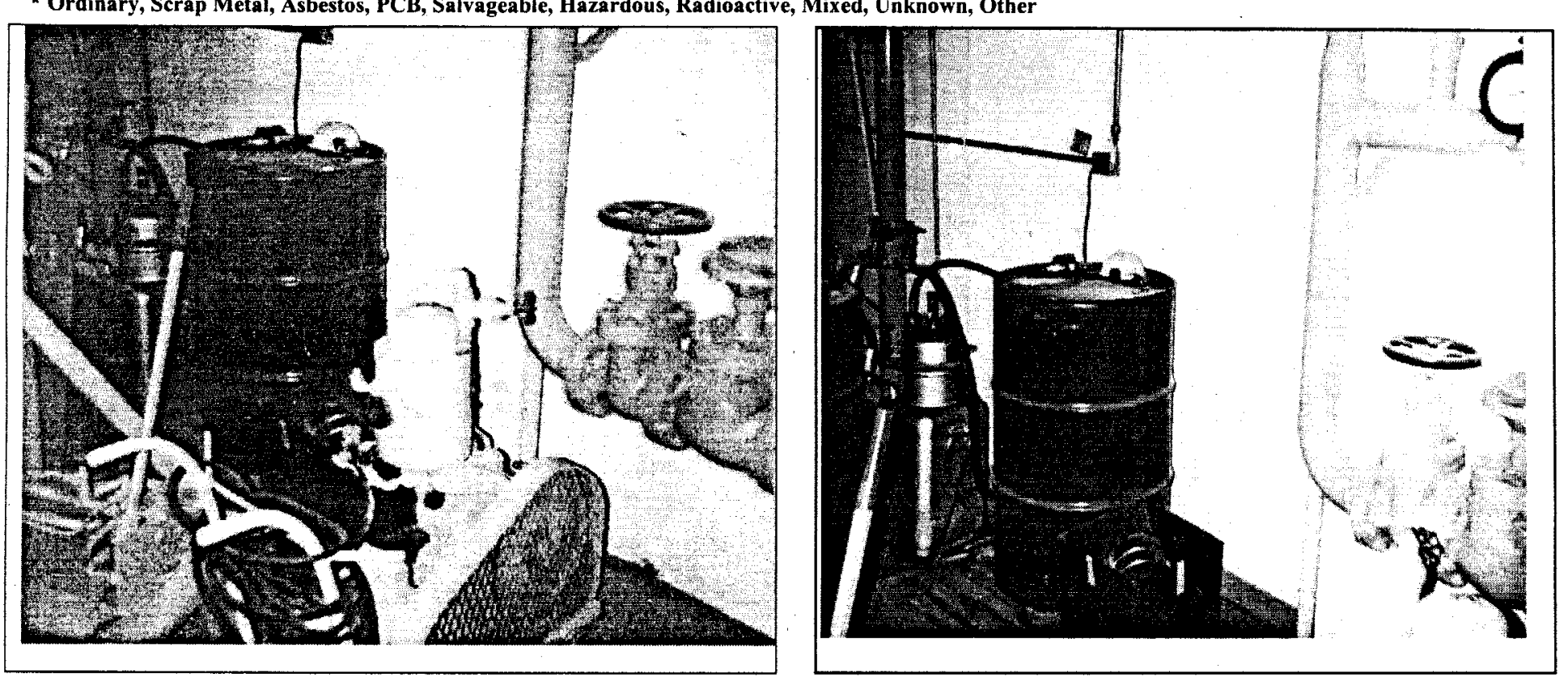

CAS Prior Status- December 20, 1990

CAS Current Status- April 30, 1997

Current Site Description/Observations: The CAS was originally identified on December 20, 1990, when it was verified that some drums had been removed, but remaining drums were still in use. The CAS field file contained an October 1991 note to file stating that the "drums remaining are attached to equipment which is used occasionally." The drums contain usable product (hydraulic fluid). The materials at this location have not been relinquished for disposal and are of no environmental concern.

No Further Action Required at Corrective Action Site - Moved to CAU 5000 in Appendix II

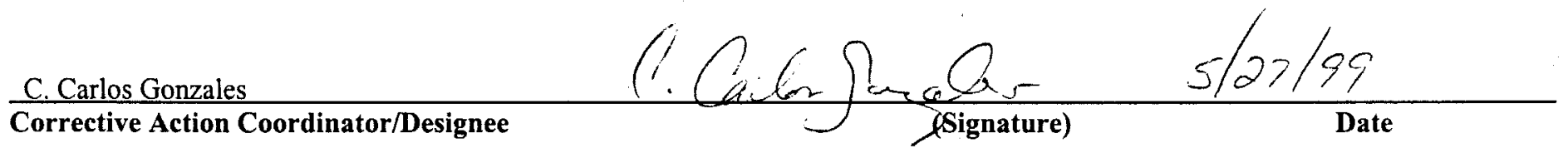




\section{FFACO CORRECTIVE ACTION SITE HOUSEKEEPING CLOSURE VERIFICATION FORM}

Closure Verification Date: April 30, 1997

CAS Number: 25-24-16

General Location: E-MAD Facility

Latitude:

Longitude:

\author{
CAU Number: 354 \\ Elevation: \\ Northing: 748,500 \\ Easting: 605,500
}

Coordinate/Elevation Data Obtained from Garmen 40 Global Position System: Accuracy is within 300 feet Horizontal - Vertical Varies with Locality

Site Access Route: From Mercury, proceed southwest on Jackass Flats Road to Area 25, through Gate 500. Proceed north on C-Road and turn left (west) on H-Road. At E-MAD turnoff, turn left (south) into the fenced compound. The batteries are located on the first floor in Room 105, Boiler Room.

\begin{tabular}{|l|l|}
\hline \multicolumn{1}{|c|}{ Waste Item(s) Originally at Site } & \multicolumn{1}{|c|}{ Apparent Waste Type* $^{*}$} \\
\hline Batteries & Recyclable \\
\hline * Ordinary, Scrap Metal, Asbestos, PCB, Salvageable, Hazardous, Radioactive, Mixed, Unknown, Other
\end{tabular}

* Ordinary, Scrap Metal, Asbestos, PCB, Salvageable, Hazardous, Radioactive, Mixed, Unknown, Other

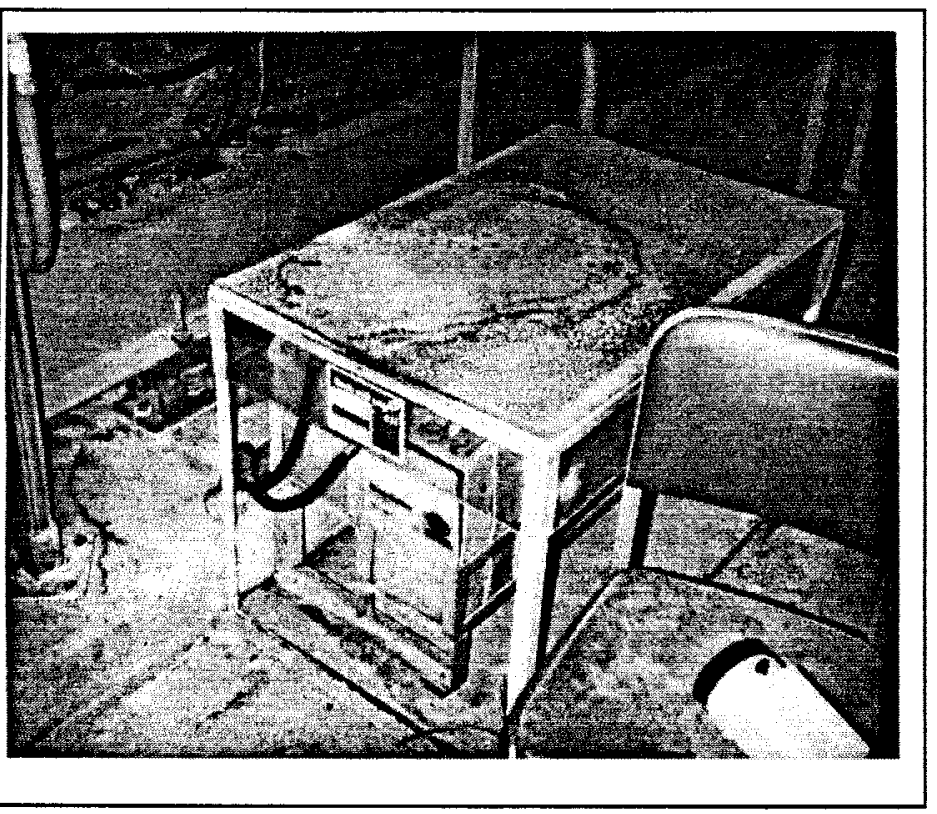

CAS Current Status- April 30, 1997

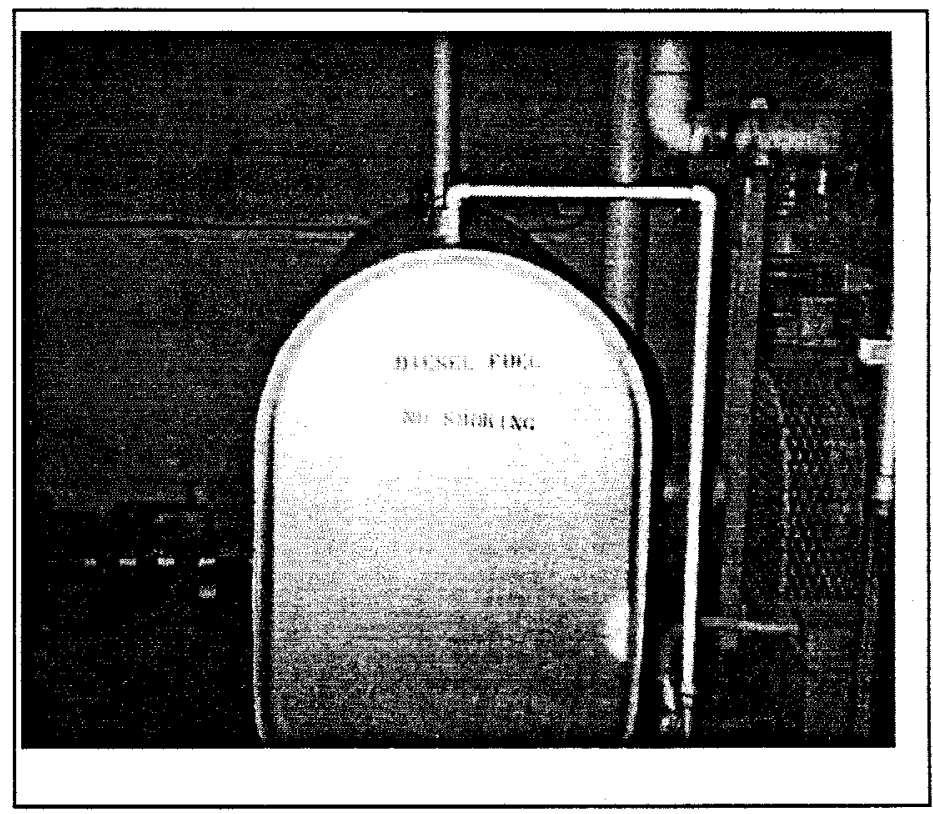

CAS Current Status- April 30, 1997

Current Site Description/Observations: NTS personnel verified that this location has a rack of batteries and an above-surface diesel tank which are still in periodic use inside the E-MAD Facility Boiler Room. Approximately 150 gallons of product was removed in July 1995 from the above-ground storage tank as part of the associated underground storage tank closure. The empty tank remains on-site and is in good condition. The batteries also remain on-site and in good condition. The materials at this location have not been relinquished for disposal and are of no environmental concern.

No Further Action Required at Corrective Action Site - Moved to CAU 5000 in Appendix II

C. Carlos Gonzales

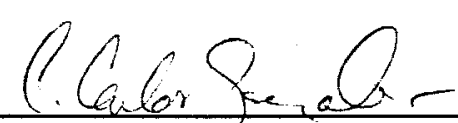
(Signature)

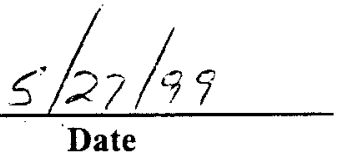




\section{FFACO CORRECTIVE ACTION SITE HoUSEKEEPING Closure VERIFICATION FORM}

Closure Verification Date: April 30, 1997

CAS Number: 25-27-01

General Location: Test Cell C

Latitude:

CAU Number: 354

Elevation:

Northing: 758,000

Longitude:

Easting: 616,000

Coordinate/Elevation Data Obtained from Garmen 40 Global Position System: Accuracy is within 300 feet Horizontal - Vertical Varies with Locality

Site Access Route: From Mercury, proceed southwest on Jackass Flats Road to Area 25, through Gate 500. Proceed north on C-Road and turn left (west) on J-Road. Follow J-Road, which curves towards Test Cell C. The CAS is on a concrete pad southeast of the Test Cell $\mathrm{C}$ compound, east of the operations building, outside the compound fence.

\begin{tabular}{|l|l|}
\hline \multicolumn{1}{|c|}{ Waste Item(s) Originally at Site } & \multicolumn{1}{c|}{ Apparent Waste Type $^{\star}$} \\
\hline Drums & Polychlorinated Biphenyls \\
\hline
\end{tabular}

* Ordinary, Scrap Metal, Asbestos, PCB, Salvageable, Hazardous, Radioactive, Mixed, Unknown, Other

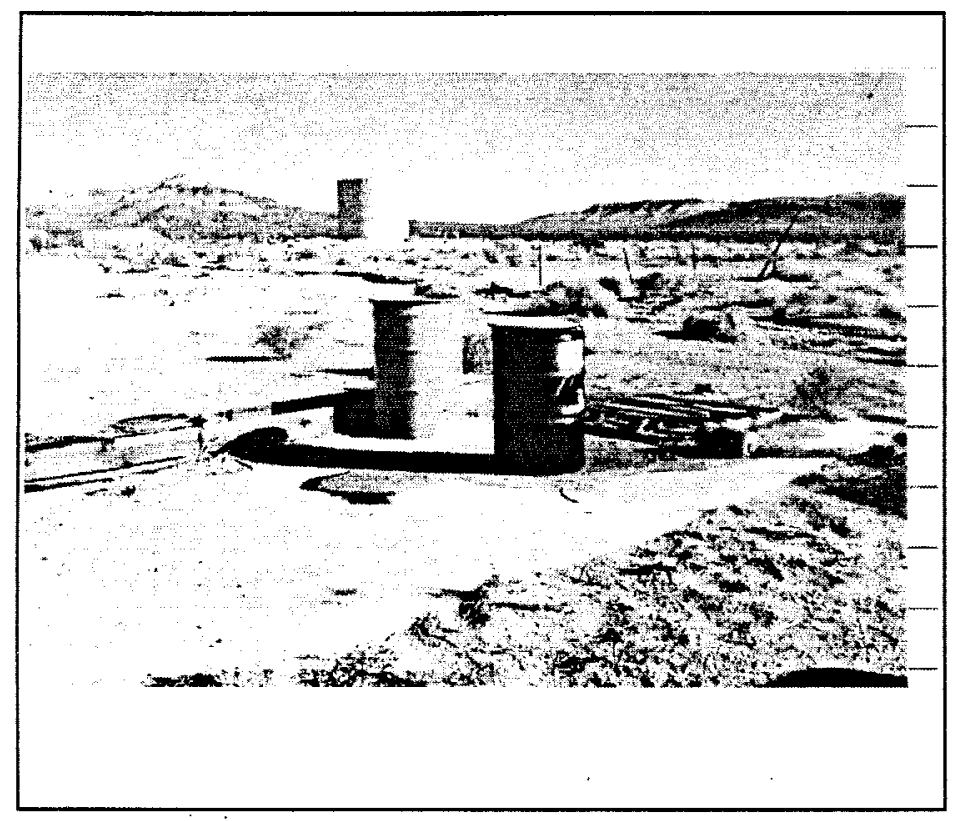

CAS Prior Status- September 25, 1990

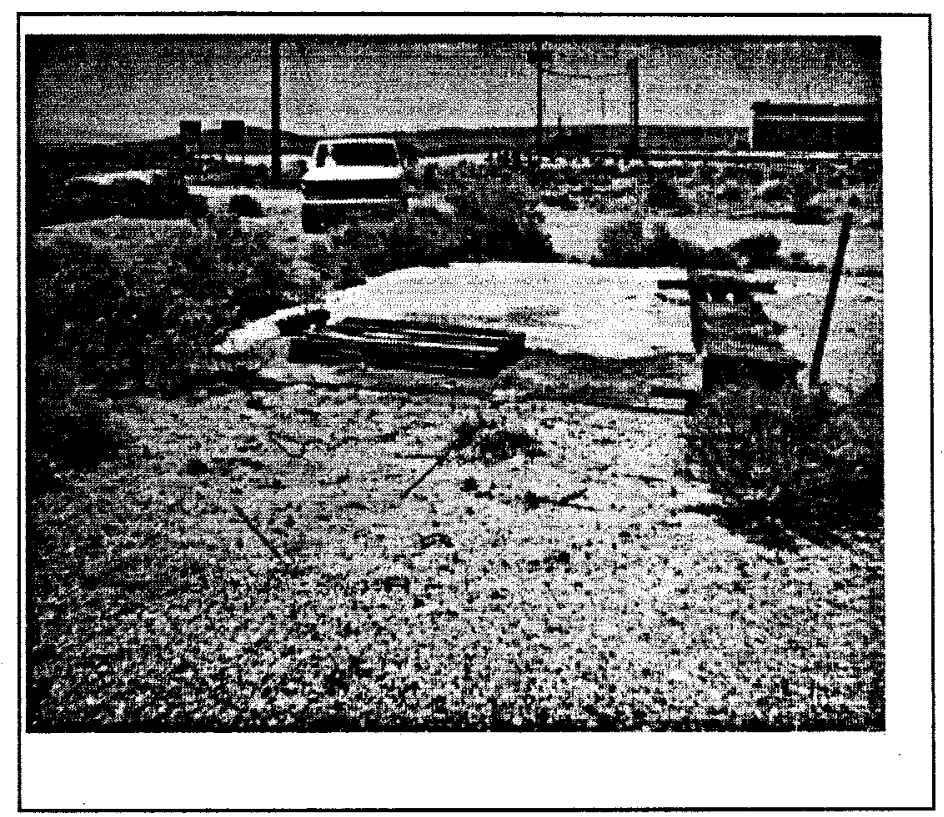

CAS Current Status- April 30, 1997

Current Site Description/Observations: The CAS was originally identified on September 20, 1990. File documentation indicates that the drums were removed in 1991 and transported to the Area 6 Polychlorinated Biphyenal Storage Facility prior to being shipped offsite to a permitted disposal facility. Approximately 55-gallons of soil staining remains at this location, as well as stained concrete, wood, and metal debris. This waste requires corrective actions that fall outside the scope of Housekeeping Category scope of work.

Stained soil was transferred to a new CAS 25-44-03 and grouped with CAU 398, Area 25 Spill Sites

$\frac{\text { C. Carlos Gonzales }}{\text { Corrective Action Coordinator/Designee }} 5 / 2799$




\section{DISTRIBUTION LIST}

\section{Nevada Division of Environmental Protection}

Paul Liebendorfer

Bureau of Federal Facilities

Division of Environmental Protection

333 W. Nye Lane, Room 13B

Carson City, NV 89706-0866

Michael McKinnon, Las Vegas Office

Bureau of Federal Facilities

Division of Environmental Protection

555 E. Washington, Suite 4300

Las Vegas, NV 89010-1043

U.S. Department of Energy, Nevada Operations Office

Environmental Restoration Division

U.S. Department of Energy, Nevada Operations Office

P.O. Box $98518 \mathrm{M} / \mathrm{S} 505$

Las Vegas, NV 89193-8518

Janet Appenzeller-Wing

Clayton Barrow

Sabrina Lawrence

U.S. Department of Energy, Nevada Operations Office

Public Reading Facility

P.O. Box $98521 \mathrm{M} / \mathrm{S}$ NLV040

Las Vegas, NV 89193-8521

U.S. Department of Energy, Nevada Operations Office

Technical Information Resource Center

P.O. Box $98521 \mathrm{M} / \mathrm{S} 505$

Las Vegas, NV 89193-8521

U.S. Department of Energy, Nevada Operations Office Office of Scientific and Technical Information

175 Oak Ridge Turnpike

P.O. Box 62

Oak Ridge, TN 37831-0062 


\section{DISTRIBUTION LIST (continued)}

\section{Bechtel Nevada}

P.O. Box 98521

Las Vegas, NV 89193-8521

Correspondence Control

David Cowser

Ann Heidema

Steve Nacht

Shannon Parsons-DePry 